\title{
Refusal by parents to give consent for medical treatment for their minor children on religious grounds
}

\author{
L.B.L.de Alwis \\ Retired Chief Consultant Judicial Medical Officer, Colombo, Sri Lanka
}

${ }^{*}$ Corresponding author: Tel: 2957050.

In Sri Lanka a minor include any person below the age of 18 years. These include newborn infants, very young children (pre-School) and young school going children who cannot understand the nature of their illnesses or give valid consent for the treatment available due their "immaturity".

Such minors are dependent on their parents for their food, shelter, education and in fact for everything they need and will not go against the wishes of their parents. This leaves the door open for parents to refuse to give consent for medical treatment for their minor children based on religious grounds even when such medical treatment is beneficial to the child and at times "life saving". Such refusal to give consent for medical treatment for their minor children by parents has resulted in the deaths or permanent disablement of such minor children.

Such refusal of parents to give consent for life saving and essential forms of medical treatment for their minor children based on religious grounds will never ever be condoned by a civilized society. It is also against the Laws of humanity and common law as the right to treatment is a basic human right. Such parents who refuse to give consent for medical treatment of minor children must realize that "they" themselves are alive today and free of disablements were because "their" parents provided them with proper medical care instead of resorting to fanatic (lunatic) religious beliefs which "they" are practicing now on "their" innocent minor children who are simply helpless.

Doctor's duty when parents refuse to give consent for medical treatment of their minor children on religious grounds.

1. In case of medical emergency, the doctor requires no consent from a parent to administer life saving or essential treatment for a minor as to preserve life is the primary ethical obligation. In such situation the doctor can ignore the expressed wishes of the parents as not to give such life saving or essential treatment. Such decisions taken by a doctor in the best interest of the helpless minor child will always be upheld by a Court of Law except under very exceptional circumstances. [1] The doctor is also covered by the principle that the doctor acted "out of necessity". A minor who later becomes an adult when informed about the decision taken by the doctor to save his life or to have prevented serious physical disabilities despite protests by his parents would praise and respect such doctor for having saved his life or prevented serious physical disabilities. Similarly if a minor child when he is an adult later in life becomes aware that his present disability was due to his parent's refusal to give consent for vital medical treatment on religious grounds would not only curse his parents and may even sue the parents for the damages which resulted due to failure to provide him with the necessary treatment on religious grounds. In fact such a minor when an adult may choose a religious belief "opposite" to that of his parents. 
2. When parents refuse to give medical treatment to a minor child on religious grounds which includes life saving blood transfusions and other life saving measures or any other form of treatment for the benefit of the child (in the best interest of the child), then the doctor treating such child or the hospital authorities where such minor child is admitted for treatment can request a Court of Law to take such minor child "into its care". This is referred to as "Parens Patriae Jurisdiction" or "Ward ship". The origin of the "Ward ship" jurisdiction is based on the duty of the crown to protect its subjects particularly children who are the generations of the future .The supreme court of Canada has ruled that to allow parents to refuse blood transfusions to their children for religious reasons undermines the ability of the state to exercise "Parens Patriae Jurisdiction" [2].

In such situations the court can give authority to the doctor to carry out any treatment based on his good clinical judgment in the best interest of the minor child. Such directions given by a court of law are Absolute and no parent can take legal action against a doctor for carrying out such court orders when treating minors. In fact case law indicates that no court of law has had any doubt that a blood transfusion should be authorized when medical considerations demanded such a need. Blood transfusions were authorized by a court of law on a 4 Year old child whose parents objected to it on religious grounds not withstanding that it was a nonemergency situation. [3]

Justice Thorpe in a case involving parents refusing blood transfusion for their 4 year old child stated that the test must remain the welfare of the child as the paramount consideration while there were risks attaching to the procedure the doctors wish to adopt the chances of success were significantly higher than a treatment regime which did not involve the use of blood transfusions or blood products [4].

All forms of refusal of consent for life saving and other beneficial treatment for minor children by parents in the guise of 'faith healing" must also be extended to include the practices of "bali, thovil" or similar rituals by charlatans who knowingly mislead parents by falsely stating that they possess a "total cure" for the illness of the minor child often charging several thousands of rupees when a total cure is in fact available or a government hospital "free of charge" or in a private medical institution of such parent's choice for a "fee".

3. At times when parents refuse to give consent to even ordinary medical treatment on religious grounds, then the doctor can proceed to treat the minor disregarding parental objections if such a minor is a "Mature Minor". Such a mature minor is capable of understanding the nature of the illness, the treatment available and the outcome of the illness if not treated. Such minors are legally termed "Gillick Competent" [5]. Such mature minors are usually in the age range of 12 years to 18 years and are mostly school going children. Lord Scarman stated that the term " Gillick Competent "is now a part of Medico-Legal Lore [6].

to give consent for a life saving or other essential treatment to a minor by parents .

Such refusal by parents to give consent for life saving or other essential treatment to a minor child will not be upheld by a court of law except under very extra-ordinary situations[9].

1. Failure to give consent for life saving or other essential forms of treatment for their minor children amounts to a crime. Such action by parents contravenes provision of the Penal Code of Sri Lanka under section 308A (1) and (2) and Section 298 .These sections refer to child neglect/child cruelty 
and causing death by a negligent act [7]. Deaths of minor children by such acts of parents may also amount to "Manslaughter" and can be charged for "Culpable Homicide" (Not amounting to murder) under section 293 of the Penal Code of Sri Lanka [7].

2. The Supreme Court of Canada has ruled that a family refusing treatment for their minor children based on religious backgrounds is a "dangerous place" for minor children [2].

3. Case Law -A Rastrafaren couple who has refused to allow their diabetic child to be given insulin was convicted of manslaughter in 1993[8].

4. Lord Donaldson in judgment stated that "very small" children who are incompetent minors must be protected by the crown (state) as they are the generations of the future[2].

5. Lord Frazer stated that Parental rights to control a child exist not for the benefit of the parent but for the benefit of the child.

6. Lord Scarmen stated in the House of lords that when a minor is "Gillick Competent "parental objections are ignored as parental rights are only are derived from a parental duty and exist only as long as they are needed for the benefit of the child.

7. In a well known American case it was stated that "parents may be free to become Martyrs themselves, but it does not follow that they are free in identical situations to make Martyrs or their children" [10].

\section{References}

1. Mason JK, McCall Smith RA, Laurie GT. Law and Medical Ethics. $6^{\text {th }}$ Edition 2002. Butterworths 10.18( $P$ 315) and 10.33(P 321).

2. B.V.Children Aid Society of Metropolitan Toronto (1995) 1. SCR 315 at 437.

3. Re.S (a minor).Medical Treatment-(1993) 1 FLR 376.

4. Re.T (a minor). (Wardship Medical Treatment)-(1997) . ALL ER 906, (1996) 35 BMLR 63.

5. Gillick V.West Norfolk and Wesbech area Health Authority (1986) AC 112, (1985) 3 ALL ER 402

6. Re. $\mathrm{R}$ (a minor)- (Wardship Medical Treatment)-(1992) FAM ii (1992),7,BMLR 147 at 156, CA, per Lord Donaldson.

7. Legislative Enactments of Ceylon, Penal Code sections 298, $308(A)(1)$ and (2) and Setion 293

8. R.V. Senior (1899) I.Q.B.283 and D. Brahmans 'Religious Objections Vs Parental duty I.Q.B.283 and D. Brahmans 'Religious Objections Vs Parental Duty (1993) 345 Lancet 1189.

9. Court of Appeal in Re T (a minor) (Wardship medical Treatment)-(1997) 1 ALL ER 906 (1996) 35 BMLR 63.

10. People (ex-rel Wallace) v Labrenz 104 NE 2 d 769 (ILL,1952) 